Author has nothing to disclose with regard to commercial support.

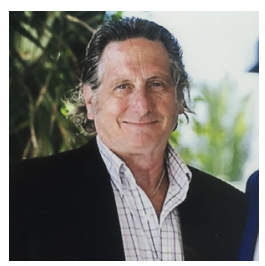

\section{HERCULEAN EFFORTS AND STANDARDIZING VALVE LABELING} To the Editor:

The European Association for Cardio-Thoracic Surgery-The Society of Thoracic Surgeons-American Association for Thoracic Surgery Valve Labelling Task Force has set out a clear and compelling argument as to why there is a scientific need for standardized labeling of heart valves. ${ }^{1}$ From the surgeon's point of view, the failure to standardize the labeling of heart values would mean that values would continue to be evaluated in "apples to oranges" comparisons. On the other hand, valve manufactures would prefer the status quo labeling system because of its lack of market transparency, which leads to greater profits.

The US Food and Drug Administration (FDA) controls the labeling of medical devices. ${ }^{2}$ Briefly, these regulations state that manufacturers of medical devices must adhere to labeling requirements that have been approved by the FDA. A manufacturer who fails to comply with FDA's labeling requirements faces civil and criminal liability for misbranding. Conceptually, then, the easiest way to standing the labeling for heart valves is to lobby the FDA for such regulations.

The bad news is that there is a vast difference between the capacity of cardiothoracic surgeons and the capacity of medical device manufacturers to lobby the FDA. In 2018, Medtronic spent $\$ 4.8$ million on lobbying. ${ }^{3}$ To match this figure, the country's approximately 4000 cardiothoracic surgeons would need to contribute approximately $\$ 1200$ each to an appropriate political action committee. Importantly, this collection of $\$ 1200$ contributions would only match what Medtronic alone spent on lobbyingallowing all the other medical device manufacturers' lobbying dollars to go unmatched.

Dollars spent on lobbying by medical device manufacturers go a long way in exerting influence on the

\footnotetext{
The Editor welcomes submissions for possible publication in the Letters to the Editor section that consist of commentary on an article published in the Journal or other relevant issues. Authors should: $\bullet$ Include no more than 500 words of text, three authors, and five references. • Type with double-spacing. • See http://jtcs.ctsnetjournals.org/ misc/ifora.shtml for detailed submission instructions. • Submit the letter electronically via jtcvs.editorialmanager.com. Letters commenting on an article published in the JTCVS will be considered if they are received within 6 weeks of the time the article was published. Authors of the article being commented on will be given an opportunity of offer a timely response ( 2 weeks) to the letter. Authors of letters will be notified that the letter has been received. Unpublished letters cannot be returned.
}

FDA. For example, FDA regulations require device manufactures to file publicly available MAUDE (Manufacturer and User Facility Device Experience) reports when a medical device is found to have "suspected device-associated deaths, serious injuries and malfunctions." ${ }^{4}$ And yet, despite its own regulations, since 2016, the FDA has allowed medical device manufacturers to conceal 1.1 million MAUDE events in a secrete database. ${ }^{5}$ Accordingly, if the FDA administrators are willing to aid and abet medical device manufacturers in the concealment of adverse events, it seems unlikely the FDA will promulgate regulations mandating uniform labeling requirements for heart valves.

The Valve Labelling Task Force is to be commended for its herculean efforts to compile the literature on factors that affect heart valve performs. But an ever larger herculean effort will be required to standardize the labeling requirements for heart valves.

\section{Thomas R. McLean, MD, JD Third Millennium Consultants, LLC Shawnee, Kan}

\section{References}

1. Durko AP, Head SJ, Pibarot P, Atluri P, Bapat V, Cameron DE, et al; EACTS-STSAATS Valve Labelling Task Force. Characteristics of surgical prosthetic heart valves and problems around labeling: a document from the European Association for Cardio-Thoracic Surgery (EACTS)—The Society of Thoracic Surgeons (STS)-American Association for Thoracic Surgery (AATS) valve labelling task force. J Thorac Cardiovasc Surg. 2019;158:1041-54.

2. US Food and Drug Administration. CFR - Code of Federal Regulations. Title 21-Food and Drugs-Chapter I-Food and Drug Administration, Department of Health and Human Services: Subchapter H-Medical Devices: Part 801Labeling. Available at: https://www.accessdata.fda.gov/scripts/cdrh/cfdocs/cfcfr/ CFRSearch.cfm?fr=801.1. Accessed October 5, 2019.

3. The Center for Responsive Politics. Client profile: Medtronic Inc. Available at https://www.opensecrets.org/lobby/clientsum.php?id=D000022110\&year= 2018. Accessed October 5, 2019.

4. US Food and Drug Administration. MAUDE-Manufacturer and user facility device experience. Available at: https://www.accessdata.fda.gov/scripts/cdrh/ cfdocs/cfmaude/search.cfm. Accessed October 5, 2019.

5. Jewett C. Hidden reports masked the scope of widespread harm from faulty heart device. Kaiser Health News. Available at: https://californiahealthline.org/news/ hidden-reports-masked-the-scope-of-widespread-harm-from-faulty-heart-device/. Accessed October 5, 2019

\section{https://doi.org/10.1016/j.jtcvs.2019.10.144}

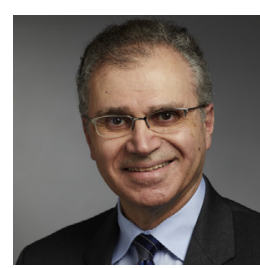

REPLY: FOCUS:
DIAMETERS AND
GRADIENTS, NOT
COMMERCE OR
REGULATIONS
Reply to the Editor:
We thank Dr
conveying in his Letter to the Editor $^{1}$ his thoughtful appreciation of the intensive efforts made by the EACTSSTS-AATS Valve Labelling Task Force. Indeed, these efforts included lengthy in-person meetings and animated 
Dr Elefteriades discloses Founder and Principal, CoolSpine; Data and Safety Monitoring BoardVascutek; Data and Safety Monitoring BoardJarvik Heart; and Consultant-CryoLife.

and erudite discussions by expert participants from multiple specialty areas, as well as detailed, organized, shared writing assignments. The panel was truly multicontinental and multinational.

Dr McLean's letter is addressed in response to our Commentary $^{2}$ regarding the first Task Force publication. ${ }^{3}$

We, the authors of the Editorial, simply do not have expertise in the commercial, regulatory, and political issues raised by Dr McLean. It appears that he has considerable knowledge in those areas. He has shared some discouraging insights through his Letter and his pertinent references.

We confined our Editorial comments to academic, clinical, and scientific topics. We cannot comment meaningfully on Dr McLean's observations and cautions.

On an optimistic note, we are pleased to report that multiple valve manufacturers and multiple regulatory agencies, including the US Food and Drug Administration, were represented in the Task Force meetings. They voiced their perspectives frankly and constructively. We are very hopeful that substantial, fruitful progress will be made on the basis of the deliberations and publications of the Task Force. We are optimistic that the standardized guidelines recommended by the Task Force will come to fruition.

We thank Dr McLean for contributing a "real-world" perspective to what has been a serious scientific and academic endeavor.

John A. Elefteriades, $M D, P h D$ (hon) Aortic Institute

Yale-New Haven Hospital New Haven, Conn

\section{References}

1. McLean TR. Herculean efforts and standardizing valve labeling. J Thorac Cardiovasc Surg. 2020;159:e259.

2. Elefteriades JA, Zafar MA, Ziganshin BA. Commentary: toward truth in advertising. J Thorac Cardiovasc Surg. 2019;158:1055-7.

3. Durko AP, Head SG, Pibarot P, Alturi P, Bapat V, Cameron DE, et al. Characteristics of surgical prosthetic heart valves and problems around labeling: a document from the European Association for Cardio-Thoracic Surgery (EACTS) - the Society of Thoracic Surgeons (STS)_American Association for Thoracic Surgery (AATS) valve labelling task force. J Thorac Cardiovasc Surg. 2019;158:1041-54.

https://doi.org/10.1016/j.jtcvs.2019.11.054 